\title{
Posterior Slope of Tibial Plateau in Adult Nigerian Subjects
}

\author{
Inclinación Posterior de la Meseta Tibial en Sujetos Nigerianos Adultos
}

"Blessing C. Didia \& **Bessing N. R Jaja

DIDIA, B. C. \& JAJA, B. N. R. Posterior slope of tibial plateau in adult Nigerian subjects. Int. J. Morphol., 27(1):201-204, 2009.

SUMMARY: Normal values of the tibial slope are necessary for realignment of displaced fractures of the tibia crest, repair of cruciate ligaments and correction of knee deformities. True lateral radiographs of normal knees were obtained in 119 males and 93 female Nigerian subjects. The tibial slope was then measured according to the anterior tibial cortex method. Mean angle in sampled subjects was $12.3 \pm 4.90$ (range: 0-240). Sex differences were statistically insignificant $(\mathrm{p}>0.05)$. This study provides reference values of tibial slope among indigenous adult Nigerians. It also highlights on the clinical relevance of the angle and the need to establish normal ranges in other African populations.

\section{KEY WORDS: Knee; Osteometry; Kinematics; Africans; Radiographs.}

\section{INTRODUCTION}

The tibia is the large weight bearing medial long bone of the leg. Besides the femur, it is the longest and largest bone in the human body (Moore \& Dalley, 1999). Its proximal end is widened and presents a plateau consisting of medial and lateral condyles and an intercondylar eminence, which articulates with the femoral condyles and intercondylar fossa respectively to form the knee joint (Moore \& Dalley; Sinnatamby, 2000). The angle formed by the posterior inclination of the tibia plateau and a line perpendicular to the middiaphysis of the tibia is called the Tibial slope or Tibial plateau angle (Moore\& Harvey, 1974; Giffin et al., 2004). The tibial slope contributes to knee stability (Shoemaker et al., 1982).

Fractures of the tibia plateau and injuries to its associated ligaments are common in athletes, but may also occur following road traffic injuries. The mechanism of injury has been related to axial compression with valgus and varus forces applied directly to the side of the knee (Solomon et al., 2001).

Anatomic restitution of depressed fractures of tibia plateau and decisions on repair procedures of torn cruciate ligaments may require measurement of the posterior slope of the tibial plateau (Noyes et al., 2005). This angle is also taken into consideration in planning for corrective osteotomies to restore normal alignment of the leg in certain knee deformities, for instance, some cases of abnormal knee hyperextension and standing varus recurvatum (Naudie et al., 2004).

Normal values of the angle of the tibial plateau have been reported in Caucasian and in Asian populations. There is paucity of studies on knee kinematics in African subjects and standards of tibial plateau angle in our environment are based on studies carried out among Caucasians. The possibility of racial differences in this angle has not been adequately investigated. It is to provide reference values of tibial plateau angle in adult Nigerian subjects that this study was undertaken.

\section{MATERIAL AND METHOD}

We studied true lateral radiographs of the knee in 119 males and 93 female indigenous Nigerian subjects between the age ranges of 21-45 years. The films were selected from the records of the radiology department of six tertiary hospitals in Nigeria, namely; Lagos University Teaching Hospital

\footnotetext{
* Department of Human Anatomy, Faculty of Basic Medical Sciences, College of Health Sciences, University of Port Harcourt, Nigeria.
}

** Department of Orthopaedic Surgery, University of Port Harcourt Teaching Hospital, Port Harcourt, Nigeria. 
(LUTH); Lagos State University Teaching Hospital (LASUTH); National Orthopaedic Hospital, Igbobi; Braithwaite Memorial Specialist Hospital, Port Harcourt, University of Port Harcourt Teaching Hospital, Port Harcourt and The Federal Medical Centre, Yenagoa.

The radiographs had been taken in the investigation of musculoskeletal problems in the limbs and only those that were adjudged normal in this respect were selected. Each radiograph was placed on an X-ray viewer and the posterior slope of the tibial plateau measured by drawing a straight line with a chinagraph pencil tangential to the tibia crest. A second line was drawn tangential to the proximal tibial articular surface and to intersect the first line. From the point of intersect, a third line was drawn perpendicular to the tibial crest line. The tibial slope was then measured with a protractor as the intersection between the second and third lines (Fig.1). Our technique was according to the anterior tibial cortex method (Noyes et al.).

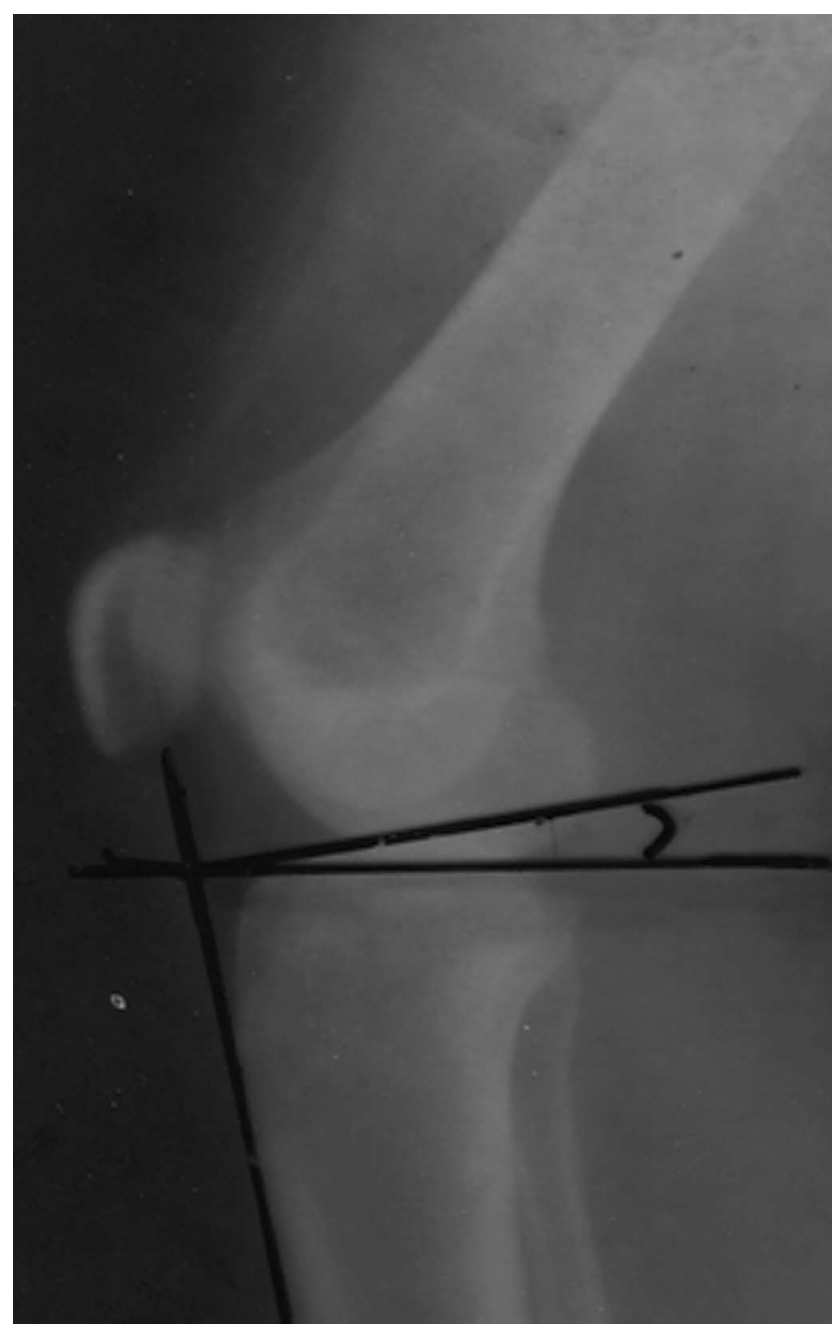

Fig.1. Posterior angle of the tibial plateau according to the anterior tibial method of measurement.
A single observer measured the angles with each angle measured twice and the average of the two taken. Intraobserver variability was less than 10 . The obtained data were subjected to simple statistical analysis and test of significance done with student's t-test for unmatched pairs.

\section{RESULTS}

Table I show the mean values and ranges of the posterior slope of tibial plateau in the Nigerian subjects whose radiographs were sampled. Differences in angle values between the right and the left limbs and between the sexes were statistically insignificant $(\mathrm{p}>0.05)$.

Table II is a comparison of the tibial slope in some population groups, in whom this angle has been measured previously, using the anterior tibial cortex method. Mean angle in the sampled subjects were significantly lower than values in Chinese and American subjects $(\mathrm{p}<0.05)$; but statistically not different from the value obtained previously among French subjects ( $\mathrm{p}>0.05)$.

\section{DISCUSSION}

The tibial slope is essential in knee biomechanics, both for ligament function and knee kinematics (Cullu et $a l ., 2005)$. Comparative studies have shown that it is steepest in the sheep and dog and shallowest in humans, with the horse tibial slope being of intermediate value (Gupte et al., 2007). Among human fossil species, the angle varies very little and attempts to discriminate among locomotors modes in hominoids based on the curvature of the tibia condyle have been of limited success (Organ \& Ward, 2006).

In humans, the obliquity of the tibial slope appears to be highly variable in the general population (Noyes et $a l$.). This was also the finding in this study. Studies using similar methods in Americans, French and Chinese subjects have shown a narrower range of variation as compared to our Nigerian subjects (Table II); with the narrowest range being that of 50 to 100 reported by Bohler as early as 1958 . Given the small sample size of most previous studies on the topic, the likelihood of regional variation could not be ascertained in this report. Nevertheless, the variability of the angle in the general population justifies the need for it to be widely measured to establish reference values in different African populations, more so considering its clinical significance in the operative management of orthopaedic conditions of the knee. 
DIDIA, B. C. \& JAJA, B. N. R. Posterior slope of tibial plateau in adult Nigerian subjects. Int. J. Morphol., 27(1):201-204, 2009.

Table I. Mean values and range of tibial plateau angle for sex and limb of sampled Nigerian subjects.

\begin{tabular}{lccccccccc}
\hline & \multicolumn{3}{c}{ Right limb } & \multicolumn{3}{c}{ Left limb } & \multicolumn{3}{c}{ Both limbs } \\
\cline { 2 - 11 } & $\mathrm{n}$ & Range & Mean & $\mathrm{n}$ & Range & Mean \pm SD & $\mathrm{n}$ & Range & Mean \\
Males & 45 & $0-23$ & $11.4 \pm 6.2$ & 74 & $2-21$ & $12 . .2 \pm 4.8$ & 119 & $0-23$ & $11.9 \pm 5.3$ \\
Females & 40 & $1-24$ & $12.6 \pm 5.4$ & 53 & $3-21$ & $12.1 \pm 4.9$ & 93 & $1-24$ & $12.4 \pm 5.1$ \\
Both & 85 & $0-24$ & $12.1 \pm 5.7$ & 127 & $2-21$ & $12.2 \pm 4.8$ & 212 & $0-24$ & $12 . .3 \pm 4.9$ \\
\hline
\end{tabular}

Table II. A comparison of tibial plateau angle among French,Chinese, American and Nigerian subjects.

\begin{tabular}{lllccc}
\hline \multicolumn{1}{c}{ Study } & Year & \multicolumn{1}{c}{ Subject } & n & Range & Mean \pm SD \\
\hline Moore & 1974 & Americans & 50 & $7-22$ & $14.0 \pm 3.7$ \\
Brazier et al. & 1996 & French & 83 & $3.47-20.29$ & $11.4 \pm 3.6$ \\
Chiu et al. & 2000 & Chinese & 25 & $5-22$ & $14.7 \pm 3.7$ \\
Present & 2006 & Nigerians & 212 & $0-24$ & $12.3 \pm 4.9$ \\
\hline
\end{tabular}

The tibial slope did not express sexual dimorphism among the sampled Nigerian subjects. In this regard, it is similar to the calcaneal angle (Didia \& Dimkpa, 1999) but is unlike the subpubic angle (Nwoha, 1992), which has been shown to be sexually dimorphic in Nigerians. Osteometric parameters provide a veritable means of sex differentiation in forensic anthropology. As a forensic tool therefore, the tibial slope most probably is of limited application in Nigerians.

ACKNOWLEDGEMENT .We would like to thank Ogbe Kehinde Deborah and Omo-okoro Arodovwe, who helped us in collating radiographs from the various Hospitals.

DIDIA, B. C. \& JAJA, B. N. R. Inclinación posterior de la meseta tibial en sujetos n igerianos adultos. Int. J. Morphol., 27(1):201-204, 2009.

RESUMEN: Los valores normales de la inclinación tibial son necesarios para conocer el reajuste de las fracturas desplazadas de la cresta tibial, reparación de los ligamentos cruzados y corrección de deformidades de la rodilla. Radiografías laterales de rodillas normales fueron obtenidas de 119 hombres y 93 mujeres de Nigeria. La inclinación tibial fue medida de acuerdo al método de la corteza tibial anterior. La media del ángulo de la muestra de los sujetos estudiados fue 12,3 $\pm 4,90$ (rango: 0-240). Diferencias por sexo fueron estadísticamente significativas ( $\mathrm{p}>0,05$ ). Este estudio proporciona valores de referencia de pendiente tibial en adultos indígenas nigerianos. También se destaca la relevancia clínica del ángulo y la necesidad de establecer los rangos normales en otras poblaciones africanas.

PALABRAS CLAVE: Rodilla; Osteometría; Cinemática; Africanos; Radiografías.

\section{REFERENCES}

Bohler, L. The treatment of fractures. New York, Grune \& Stratton. 1958.

Cullu, E.; Aydog `u, S.; Alparslan, B. \& Sur, H. Tibial slope changes following dome-type tibial osteotomy. Knee Surg. Sports Traumatol. Arthrosc., 13(1):38-43, 2005.

Didia, B. C. \& Dimkpa, J. N. The Calcaneal angle in Nigerians: Relationship to sex, age and size of the body. J. Am. Podiatr. Med. Assoc., 89(9):472-4, 1999.
Giffin, J. R.; Vogrin, T. M.; Zantop, T.; Woo S. L. \& Harner, C. D. Effects of increasing tibial slope on the biomechanics of the knee. Am. J. Sports Med., 32(2):37682, 2004.

Gupte, C. M.; Bull, A. M.; Murray, R. \& Arius, A. A. Comparative Anatomy of the meniscofemoral ligament in humans and some domestic mammals. Anat. Histol. Embryol., 36(1):47-52, 2007. 
Moore, K. L. \& Dalley, A. F. Clinically Oriented Anatomy. $4^{\text {th }}$. Ed. Philadelphia, Lippincott Williams \& Wilkins, 1999.

Moore, T. M. \& Harvey, J. P. Jr. Roentgenographic measurement of tibial-plateau depression due to fracture. J. Bone Joint Surg. Am., 56(1):155-60, 1974.

Naudie, D. D.; Amendola, A. \& Fowler, P. J. Opening wedge high tibial osteotomy for symptomatic hyperextensionvarus thrust. Am. J. Sports Med., 32(1):60-70, 2004.

Noyes, F. R.; Goebel, S. X. \& West, J. Opening wedge tibial osteotomy: the 3-triangle method to correct axial alignment and tibial slope. Am. J. Sports Med., 33(3):37887, 2005.

Nwoha, P. U. The anterior dimensions of the pelvis in sex determination. West Afr. J. Anat., 1:59-60, 1992.

Organ, J. M. \& Ward, C. V. Contours of the Hominoid lateral tibial condyle with implications for Australopithecus. J. Hum. Evol., 51(2):113-27, 2006.

Shoemaker, S. C.; Markolf, K. L. \& Finerman, G. A. In vitro stability of the implanted total condyle prosthesis. Effects of joint load and of sectioning the posterior cruciate ligament. J. Bone Joint Surg. Am., 64(8):1201-13, 1982.

Sinnatamby, C. S. Last's Anatomy Regional and Applied. Edinburg, Churchhill Livingstone, 2000.

Solomon, L.; Warwick, D. \& Nayagam, S. Apley's System of Orthopaedics and Fractures. London, Arnold, 2001.
Correspondence to:

Dr. Blessing N. R. Jaja

Department of Orthopaedic Surgery

University of Port Harcourt Teaching Hospital

Port Harcourt

NIGERIA

Email: jajabnr2000@yahoo.com

Received: 18-01-2008

Accepted: 26-08-2008 